HERCOS, GFL; BELISÁRIO, CM; ALVES, AES; MAIA, GPAG; CAVALCANTE, MD. 2021. Physicochemical characterization, bioactive compounds and antioxidant capacity of bitter melon. Horticultura Brasileira 39: 397-403. DOI: http://dx.doi.org/10.1590/s0102-0536-20210408

\title{
Physicochemical characterization, bioactive compounds and antioxidant capacity of bitter melon
}

\author{
Guilherme F de L Hercos ${ }^{1} \mathbb{D}$; Celso M Belisário ${ }^{1} \mathbb{D}$; Anny E de S Alves ${ }^{1} \mathbb{D}$; Geisa Priscilla AG Maia ${ }^{2} \mathbb{D}$; Maísa \\ D Cavalcante ${ }^{3 \mathbb{D}}$
}

${ }^{1}$ Instituto Federal de Educação, Ciência e tecnologia Goiano (IF Goiano), Rio Verde-GO, Brasil; guilherme.limahercos@gmail.com; celso. belisario@ifgoiano.edu.br; anny.alves@estudante.ifgoiano.edu.br; ${ }^{2}$ Universidade Estadual de Campinas (Unicamp), Campinas-SP, Brasil; geisamaia@hotmail.com; ${ }^{3}$ Universidade Estadual Paulista (Unesp), São José do Rio Preto-SP, Brasil; maisadiascavalcante@hotmail.com

\begin{abstract}
The bitter melon (Momordica charantia) is an exotic fruit that has adapted very well to the Brazilian soils, and can be found on practically all regions. Several advantages related to consumption of this fruit can be reported, highlighting its antifungal activity, reduction of glycemic indexes, and also due to the content of natural pigments, such as lycopene and $\beta$-carotene, making it promising as a functional food. Based on the demand for foods of this nature, this research aimed at the biometric characterization, physicochemical, bioactive compounds and the pulp and seeds' antioxidant capacity of bitter melon, collected in the southwest region of Goias. The fruits were collected from plants inside a native vegetation area on Campus Rio Verde at the Instituto Federal Goiano, and the evaluations were carried out from October 2020 to April 2021. The fruits showed high variability in dimensions and weight, high concentrations of flavonoids, tannins, carotenoids, total phenolics and antioxidant capacity. According to results, the bitter melon can be used as a raw material to develop food formulations with functional characteristics and drugs potentially effective in the treatment of diabetes and diseases caused by oxidative processes.
\end{abstract}

Keywords: Momordica charantia, flavonoids, tannins, carotenoids, vitamin A, antioxidant capacity.

\section{RESUMO}

Caracterização físico-química, compostos bioativos e capacidade antioxidante do melão de São Caetano

O melão de São Caetano (Momordica charantia) é um fruto exótico que se adaptou muito bem aos solos do Brasil, podendo ser encontrado em praticamente todas as regiões. Diversas vantagens relacionadas com o consumo desse fruto podem ser reportadas, destacando-se sua atividade antifúngica, redução de índices glicêmicos, e também pelo conteúdo de pigmentos naturais, como o licopeno e o $\beta$-caroteno, tornando-o promissor como alimento funcional. Partindo da demanda por alimentos dessa natureza, esta pesquisa objetivou a caracterização biométrica, físico-química, compostos bioativos e capacidade antioxidante da polpa e sementes do melão de São Caetano, coletados na região sudoeste do estado de Goiás. Os frutos foram coletados de plantas localizadas em uma área de vegetação nativa do Campus Rio Verde do Instituto Federal Goiano, e as avaliações ocorreram de outubro de 2020 a abril de 2021. Observou-se elevada variabilidade de dimensões e massas, altas concentrações de flavonoides, taninos, carotenoides, fenólicos totais e capacidade antioxidante. De acordo com os resultados, o melão de São Caetano pode ser utilizado como matéria prima para o desenvolvimento de formulações alimentícias com características funcionais e de fármacos potencialmente eficazes no tratamento de diabetes e de doenças causadas por processos oxidativos.

Palavras-chave: Momordica charantia, flavonoides, taninos, carotenoides, vitamina A, capacidade antioxidante.

Received on May 26, 2021; accepted on August 11, 2021

A mong the various plant species from Brazilian Cerrado, there is the bitter melon (Momordica charantia) (Figure 1), a plant of the Curcubitaceae family, monoecious, originating from eastern India and southern China. It presents isolated yellow flowers in the leaf axils, oblong fruits, similar to cucumber, with variable length and weight dimensions. The fruit is green when immature and mature fruits are orange (Assis et al., 2015).

This fruit is mainly consumed for therapeutic purposes, related in studies about antifungal properties (Celoto et $a l ., 2011$ ) and for treatment of diabetes mellitus (Kim et al., 2020), among others, such as cancer prevention, antiviral, antimicrobial, analgesic and anti-inflammatory action (Tan et al., 2016; Bortolotti et al., 2019; Sur \& Ray, 2020). Many of its potentials may be associated with natural pigments contents, such as lycopene and $\beta$-carotene, in addition to other phenolic compounds, which are also responsible for inhibition of oxidative processes (Macedo et al., 2017).

Being seasonal fruits, with great variability, its biometric characterization is essential, especially for future studies about improvement of the cultivar (Assis et al., 2015). Furthermore, its 
fruits are consumed for being rich in bioactive compounds and antioxidant capacity. Consequently, studies about flavonoids content (Madala et al., 2016), total phenolics (Chung et al., 2016), ascorbic acid (Ng \& Kuppusamy, 2019), among others, can validate such properties and provide high additive value to the product, which is also part of the income of families of small rural producers.

Considering other researches about the fruit, which has many potentials, this research evaluated the biometric and physicochemical data, the total phenolic compounds, vitamin $\mathrm{C}$, flavonoids, carotenoids and antioxidant capacity of bitter melon pulp and seeds, obtained in native vegetation in the Southwest of the state of Goiás.

\section{MATERIAL AND METHODS}

About $3 \mathrm{~kg}$ of fruits were harvested in October 2020, from plants in an area of native vegetation on Campus Rio Verde of the Instituto Federal Goiano, at Rodovia Sul Goiana km 01, Rural Zone, Rio Verde-GO. After collected, the fruits were sanitized and stored in a freezer at $-18^{\circ} \mathrm{C}$ until the moment of analysis. All physicochemical and antioxidant capacity evaluations were carried out with fruit pulp and seeds, in triplicate.

\section{Ascertainment of size, weight and pulp yield}

Biometric parameters were determined according to norms of Instituto Adolfo Lutz, and presented similarly to the research by Assis et al. (2015). Using precision scale and digital caliper, measurements were taken from 150 fruits, measuring longitudinal axis or length ( $\mathrm{mm})$, equatorial axis or width $(\mathrm{mm})$, fruit weight with seed $(\mathrm{g})$, pulp weight without seed (g) and pulp yield $(\%)$. To measure the weight of the fruits without seeds, they were opened manually, using a previously sanitized laboratory spatula.

\section{Moisture content}

The moisture content (\% w.b.) was determined according to Instituto Adolfo Lutz (Zenebon et al., 2008). Approximately $2.5 \mathrm{~g}$ of the sample were weighed and transferred to previously dried and tared porcelain capsules. Then, samples were taken to an oven at $105^{\circ} \mathrm{C}$ for $24 \mathrm{~h}$.

\section{Lipids}

The lipids content was measured by Bligh \& Dyer method. About $3.0 \mathrm{~g}$ were weighed in a $100 \mathrm{~mL}$ beaker, then 10 $\mathrm{mL}$ of chloroform, $20 \mathrm{~mL}$ of methanol and $8 \mathrm{~mL}$ of distilled water were added, capped and rotary stirred on a magnetic stirrer for 30 minutes. After stirring, 10 $\mathrm{mL}$ of chloroform and $10 \mathrm{~mL}$ of aqueous sodium sulphate $1.5 \%$ (w/v) were added, stirred for another 2 minutes and the layers separated in a separatory funnel. Approximately $15 \mathrm{~mL}$ of the lower layer were removed, $1 \mathrm{~g}$ of anhydrous sodium sulphate was added, capped and shaken by hand for 2 minutes. $5 \mathrm{~mL}$ of filtrate were filtered and transferred to an oven at $80^{\circ} \mathrm{C}$ for 30 minutes to evaporate the solvent. It was cooled in a desiccator and weighed again.

\section{Proteins}

Approximately $0.5 \mathrm{~g}$ of sample was weighed on tissue paper and the sample transferred to a Kjeldahl flask. Afterward, $7 \mathrm{~mL}$ of sulfuric acid and about $2.5 \mathrm{~g}$ of catalytic mixture $(90 \%$ potassium sulphate $+10 \%$ copper sulphate) were added. It was heated on an electric hotplate until the solution turned blue-green and free of undigested material. The tube containing the digested sample was connected to the distillation set, with the tapered end of the soft drink dipped in $20 \mathrm{~mL}$ of $4 \%$ boric acid with 5 drops of mixed indicator (methyl red + bromocresol green). $40 \%$ sodium hydroxide solution was added to the tube containing the digested sample, using a funnel with a stopcock, until a slight excess of base was ensured. It was heated to boiling and distilled to obtain about $75 \mathrm{~mL}$ distillate. Excess sulfuric acid was titrated with a standardized $0.1 \mathrm{~mol} \mathrm{~L}^{-1}$ hydrochloric acid solution. To determine the protein content, the values obtained in the analysis were substituted in equation 1 (Zenebon et al., 2008).

$$
\text { Protein }(\%)=\frac{V \times N \times 0,014 \times 100 \times 6,38}{m}
$$

Where:

$\mathrm{V}=$ volume of hydrochloric acid consumed (mL);

$\mathrm{N}=$ hydrochloric acid solution (mol
$\left.\mathrm{L}^{-1}\right)$

$\mathrm{M}=$ sample weight $(\mathrm{g})$.

pH measurement

The $\mathrm{pH}$ was measured by previously calibrated bench pHmeter. For this, 2 $\mathrm{g}$ of sample were placed in a beaker containing $30 \mathrm{~mL}$ water. Measurements were taken after shaking the system with a glass stick.

Determination of total titratable acidity

About $5 \mathrm{~g}$ of sample were macerated, transferred to a $100 \mathrm{~mL}$ flask, and diluted with distilled water. The titrant solution was $0.1 \mathrm{M}$ sodium hydroxide, and the indicator was $1 \%(\mathrm{~m} / \mathrm{v})$ phenolphthalein in an ethanolic solution. (Zenebon et al., 2008).

Phenolic total and tannin contents

The phenolic total content was obtained by Folin-Ciocalteu method as described by Chung et al. (2016). Approximately $3 \mathrm{~g}$ of sample were added to a $100 \mathrm{~mL}$ aqueous-alcoholic solution $50 \%(\mathrm{v} / \mathrm{v})$. The system was agitated for 24 hours, then filtrated, and finally supernatant was collected and transferred to $100 \mathrm{~mL}$ flasks and the volume was filled with aqueousalcoholic solution.

The tannin contents (\%) were determined by calibration curve using tannic acid standard, ranging from 20 to $100 \mathrm{mg} \mathrm{L}^{-1}$. Absobance readings were $760 \mathrm{~nm}$ in spectrophotometer UV/ Vis (Makkar, 2000). In test-tube were added $8.2 \mathrm{~mL}$ distilled water, $0.3 \mathrm{~mL}$ extract, $0.5 \mathrm{~mL}$ Folin-Denis's reagent and $1 \mathrm{~mL}$ aqueous sodium carbonate solution at $7.5 \%(\mathrm{w} / \mathrm{v})$. After agitation and subsequent rest for 30 minutes, absorbance readings were performed in spectrophotometer at $760 \mathrm{~nm}$. The phenolic total contents (mg GAE 100 $\mathrm{g}^{-1}$ ) were determined by calibration curve using gallic acid standard, ranging from 0 to $500 \mathrm{mg} \mathrm{L}^{-1}$.

\section{Flavonoid contents}

Total flavonoids (mg of pyrocatechin $100 \mathrm{~g}^{-1}$ ) were quantified by colorimetric method (Thiruvengadam et al., 2014), using Pyrocatechin as an analytical standard instead of Quercetin. In test-tube were added $0.5 \mathrm{~mL}$ extract, $0.3 \mathrm{~mL} \mathrm{NaNO}$ (aq) at 5\% (w/v), 0.3 $\mathrm{mL} \mathrm{AlCl}_{3}$ (methanolic) at $10 \%(\mathrm{w} / \mathrm{v})$ 
and $2 \mathrm{~mL} \mathrm{NaOH} \mathrm{(aq)} \mathrm{at} 1 \mathrm{~mol} \mathrm{~L}^{-1}$. After shaking, each tube was left to rest for 10 minutes, next, absorbance readings were performed at $510 \mathrm{~nm}$ in spectrophotometer, previously tared with aqueous-alcoholic solution $50 \%$ $(\mathrm{v} / \mathrm{v})$. The flavonoid contents were determined by calibration curve using pyrocatechin standard, ranging from 10 to $50 \mathrm{mg} \mathrm{L}^{-1}$.

\section{Vitamin C}

About $5 \mathrm{~g}$ of sample was weighed and transferred to a $300 \mathrm{~mL}$ Erlenmeyer flask with $50 \mathrm{~mL}$ distilled water. Then, $10 \mathrm{~mL}$ of sulfuric acid solution at $20 \%$ was added. After homogenization, $1 \mathrm{~mL}$ of aqueous potassium iodide solution at $10 \%(\mathrm{w} / \mathrm{v})$ and $1 \mathrm{~mL}$ of aqueous starch solution at $1 \%(\mathrm{w} / \mathrm{v})$ were added. The resulting solution was titrated with potassium iodate solution at $0.002 \mathrm{M}$, until blue color was observed. The amount of vitamin $\mathrm{C}\left(\mathrm{mg} 100 \mathrm{~g} \mathrm{~g}^{-1}\right)$ was calculated using equation 2 (Zenebon et al., 2008).

Where:

$$
\text { vit } \mathrm{C}=\frac{100 * \mathrm{v} * \mathrm{~F}}{\mathrm{p}}
$$

$\mathrm{V}=$ potassium iodate solution consumed $(\mathrm{mL})$;

$\mathrm{F}=0.8806$;

$\mathrm{P}=$ sample weight $(\mathrm{g})$.

\section{Antioxidant activity by DPPH radical assay}

The antioxidant capacity was measured according to Mensor et al. (2001), using a blend (1:1) methyl alcohol aqueous solution at $50 \%$ and acetone aqueous solution at $70 \%$ as extracting solution. The capacity of the extract to reduce the DPPH radical (2,2-diphenyl-1-picrylhydrazyl) 0.30 mmol L-1 was compared with the activity of the synthetic antioxidant trolox (6-hydroxy-2,5,7,8tetramethylchroman-2-carboxylic acid) at $100 \mathrm{mg} \mathrm{L}^{-1}$, used as positive control.

$2.5 \mathrm{~mL}$ of extract was added to $1 \mathrm{~mL}$ DPPH solution, and sample blanks consisted of $2.5 \mathrm{~mL}$ of extract and $1 \mathrm{~mL}$ of extraction solution. For positive control, $2.5 \mathrm{~mL}$ trolox and 1 $\mathrm{mL}$ DPPH were used, and its blank consisted of $2.5 \mathrm{~mL}$ trolox and $1 \mathrm{~mL}$ ethanol. The negative control of the samples and the positive control were prepared with $2.5 \mathrm{~mL}$ ethanol solution and $1 \mathrm{~mL} \mathrm{DPPH.} \mathrm{After} \mathrm{preparation,} \mathrm{the}$ solutions were stored for 30 minutes in the dark, then the absorbance was read in a spectrophotometer at $518 \mathrm{~nm}$. The antioxidant capacity was calculated from equation 3 .

AA $(\%)=100-\left[\frac{\text { Abs (sample) }- \text { Abs (blank) }}{\text { Abs(negative control })}\right]$

Where:

Abs (sample) = sample absorbance; Abs (blank) $=$ blank absorbance;

$\operatorname{Abs}($ negative control $)=$ negative control absorbance.

To calculate the antioxidant activity of trolox, used as positive control, the Abs (sample) was replaced by the positive control absorbance.

\section{Total carotenoids}

For determination of the carotenoid content $\left(\mu \mathrm{g} \mathrm{g}^{-1}\right)$, the methodology described by Souza et al. (2012) was utilized. About $5 \mathrm{~g}$ of the sample from each treatment in triplicates was macerated with about $30 \mathrm{~mL}$ cold acetone and $5 \mathrm{~g}$ of Hyflo Supercel for 2 minutes, followed by vacuum filtration. The extraction was repeated six times until the filtrate became as clear as possible.

The filtrate was then transferred to a $250 \mathrm{~mL}$ separation funnel containing $50 \mathrm{~mL}$ cold petroleum ether. Three consecutive washes were performed with $100 \mathrm{~mL}$ distilled water to remove acetone. The ether-dissolved phase was transferred to an amber flask; then, the same volume of $10 \%(\mathrm{w} / \mathrm{v}) \mathrm{KOH}$ methanolic solution was added, and the mixture was stored at room temperature for $24 \mathrm{~h}$ for saponification of lipids and chlorophyll.

This mixture was then transferred to a separation funnel containing 50 $\mathrm{mL}$ cold petroleum ether, followed by washing with $50 \mathrm{~mL}$ aliquots of distilled water until the $\mathrm{pH}$ of the ether phase was near neutral. About $3 \mathrm{~g}$ of anhydrous sodium sulfate were added, the mixture filtered, and the ether extract concentrated on a rotary evaporator $\left(35^{\circ} \mathrm{C}\right.$ and $\left.90 \mathrm{rpm}\right)$. The concentrate was transferred to a $50 \mathrm{~mL}$ balloon and diluted to the desired volume with petroleum ether.

Total carotenoid quantification was performed using the scanning method with readings from 300 to $700 \mathrm{~nm}$ in
UV/Vis spectrometer, for equation 4.

$$
\mathrm{CT}=\frac{\mathrm{Abs}^{*} \mathrm{Vol}^{*} 10^{4}}{\mathrm{E}_{1 \mathrm{~cm}}^{1 \%} * \mathrm{P}}
$$

Where:

$\mathrm{CT}=$ total carotenoids $\left(\mu \mathrm{g} \mathrm{g}^{-1}\right)$;

$\mathrm{Abs}=$ maximum absorbance;

$\mathrm{Vol}=$ dilution volume $(\mathrm{mL})$;

$\mathrm{E}_{1 \mathrm{~cm}}^{1 \%}=$ molar extinction coefficient in petroleum ether ( $\beta$-carotene: 2592$)$;

$\mathrm{P}=$ sample weight $(\mathrm{g})$.

\section{Statistical analysis}

Biometric evaluations were performed from 150 fruits, and the means of the parameters presented followed by their respective standard deviations. In addition, the results were submitted to descriptive analysis of frequency distribution and estimate of Pearson's correlation coefficient. The means of physicochemical variables, carotenoid content and antioxidant capacity were presented followed by their respective standard deviations.

\section{RESULTS AND DISCUSSION}

\section{Ascertainment of size, weight and pulp yield}

Table 1 shows the biometric parameters evaluated. The fruits had an average weight of $5.30 \pm 2.37 \mathrm{~g}$, with a high coefficient of variation. The calculated value was similar, but lower than that obtained by Assis et al. (2015) of $6.38 \mathrm{~g}$. The minimum weight value obtained was $1.35 \mathrm{~g}$, and the maximum was $3.99 \mathrm{~g}$.

The high coefficients of variation for the biometric parameters of bitter melon can be attributed to genetic variability, environmental factors (biotic and abiotic), and the genotype-environment interaction. Research on tropical fruit species shows high variability in fruit size, seed, volume and weight of fruits and seeds (Zuffo et al., 2014).

This low uniformity of biometric parameters may also be due to the fact that the fruits were collected from plants in an area of native vegetation. These plants were not inserted in that environment in a planned way, because, according to Assis et al. (2015), this species is commonly known as a weed, which develops in different places, 
without its propagation being controlled.

There was a relationship between the longitudinal axis and the equatorial axis (LA/EA) with an amplitude varying from 1.36 to 2.99 , and an overall mean of $2.04 \pm 0.28$. From this relationship it is possible to indicate the shape of the fruits, if the relationship between the axes is greater than or equal to 1 , it indicates elongated and cylindrical fruits, that is, the longitudinal diameter is greater than the equatorial diameter (Silva et al., 2016).

The characterization of the fruit's shape is very important for post-harvest handling, especially in the case of fruits destined for agro-industrial processing, because the visual aspect of the final product influences the level of acceptability by end users. In addition, industries prefer rounded fruits due to their ease of cleaning and processing (Chitarra \& Chitarra, 2005).

Figure 2 shows the normal distribution fit, as well as the number of observations of the longitudinal axis, equatorial axis, fruit weight and pulp yield of bitter melon.

The longitudinal axis of bitter melon had a mean of $39.61 \mathrm{~mm}$, with amplitude ranging from 21.7 to $61.1 \mathrm{~mm}$. In general, the values obtained were lower than results presented by Santana et al. (2013), that most fruits present a length of 49 to $57 \mathrm{~mm}$. Regarding the equatorial axis of the fruits, the values obtained

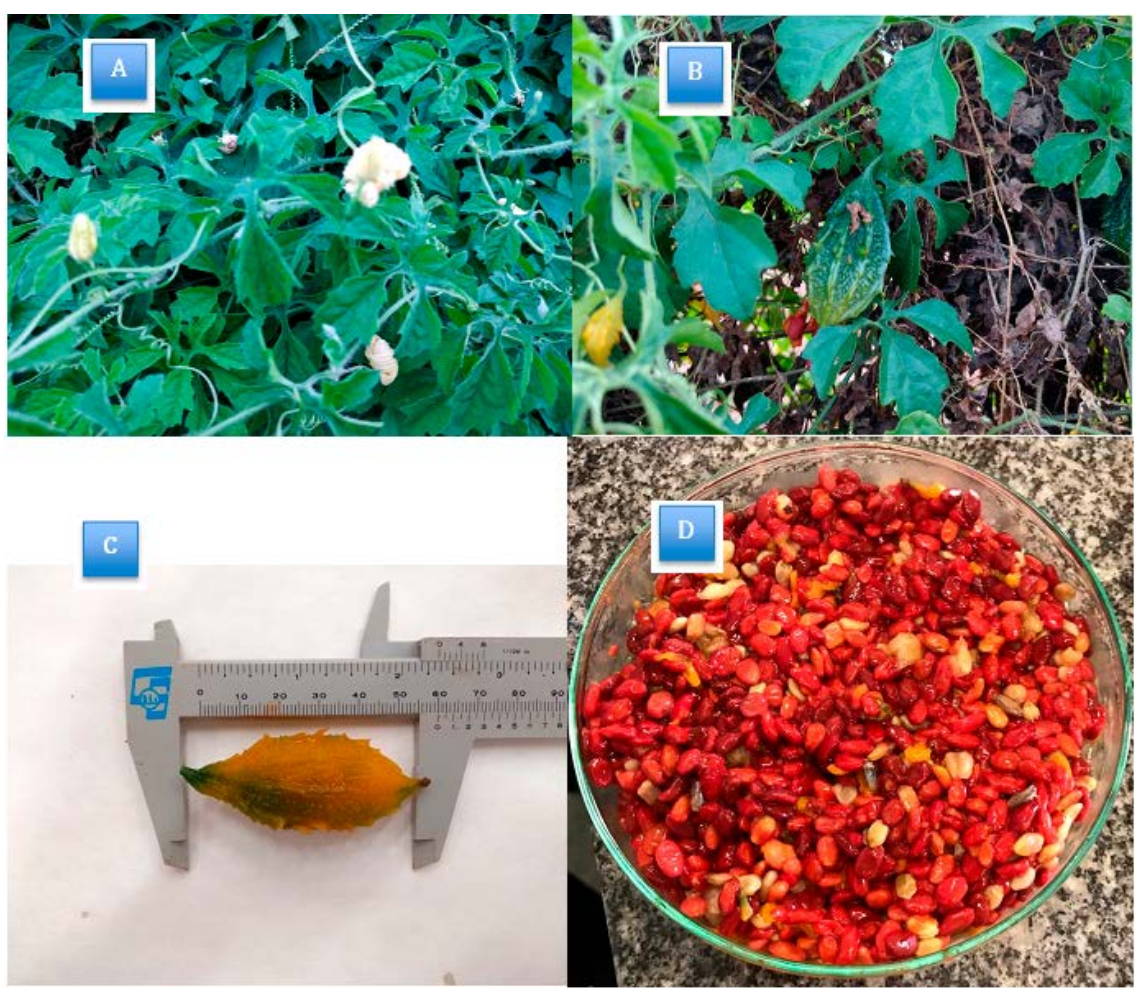

Figure 1. Overview of the bitter melon. $A=$ inflorescence; $B=$ immature fruit; $C=$ mature fruit, and $\mathrm{D}=$ fruit seeds. Photography= authors. Rio Verde, IFGoiano, 2020.

Table 1. Biometric data of bitter melon. Rio Verde, IFGoiano, 2020.

\begin{tabular}{lccccc}
\hline Parameters & Minimum & Mean & Maximum & SD & CV (\%) \\
\hline Longitudinal axis (mm) & 21.7 & 39.61 & 61.1 & 8.95 & 22.59 \\
Equatorial axis (mm) & 11.6 & 19.41 & 27.8 & 3.56 & 18.40 \\
Fruit weight (g) & 1.56 & 5.30 & 12.44 & 2.37 & 44.78 \\
Pulp yield (\%) & 50.05 & 62.02 & 77.71 & 5.54 & 8.95 \\
LA/EA & 1.36 & 2.04 & 2.99 & 0.28 & 14.10 \\
\hline
\end{tabular}

$\mathrm{LA} / \mathrm{EA}=$ ratio (longitudinal axis/equatorial axis); $\mathrm{SD}=$ standard deviation; $\mathrm{CV}(\%)=$ coefficient of variation. ranged from 11.6 to $27.8 \mathrm{~mm}$, with an average very near to highest frequency found by Santana et al. (2013), from 17 to $19 \mathrm{~mm}$. The coefficients of variation of the longitudinal axis and equatorial axis of fruits were $22.59 \%$ and $18.40 \%$, respectively, values similar to those obtained by Assis et al. (2015), of $18.08 \%$ and $13.16 \%$, respectively.

The mean pulp yield was $62.02 \%$. Carvalho \& Muller (2005) classified the pulp yield of native fruits as very low (less than 20\%), low (from 21 to $40 \%$ ), medium (from 41 to $60 \%$ ); high (from 61 to $80 \%$ ) and very high (more than $81 \%$ ). The high pulp yield of bitter melon demonstrates great feasibility of applying it in the development of products in the food and pharmaceutical industries.

From the Pearson's correlation coefficients (R) the correlation of the different physical characteristics of the fruits was determined as positively high (from 0.7 to 0.9 ) (Table 2).

The parameter that presented the highest correlation with the fruit pulp yield was the fruit weight (0.983), followed by equatorial axis $(0.879)$ and the longitudinal axis (0.859). Pedron et al. (2004), analyzing the biometric parameters of butiazeiro fruits, also observed a high correlation between weight and pulp yield.

Physicochemical parameters, bioactive compounds and antioxidante activity

The moisture content of the pulp was $86.50 \pm 1.27 \%$ (w.b.) and of seeds $56.06 \pm 2.16 \%$ (w.b.). Knowing that the pulp and the seeds are used as unconventional foods, data about their initial moisture contents are important, especially for planning the elaboration of products that depend on the drying process.

The proteins content of the pulp was $0.90 \pm 0.06 \%$. Poovitha \& Parani (2017) observed that protein extracts from $M$. charantia pulp significantly reduced blood glucose levels and improved islet morphology in diabetic rats. Momordica charantia lectin (MCL), a protein present in the fruit, has some toxicity, but it is an excellent antitumor agent that acts by inhibiting cell viability, inducing autophagy, apoptosis and cell 
cycle arrest in some cancer lines (Fang et al., 2019).

The lipid content of the pulp was $0.87 \pm 0.06 \%$; Yuwai et al. (1991), through spectroscopy studies, confirmed the presence of eleostaric acid in the fruits of Momordica charantia. Eleostaric acid is a fatty acid that has shown inhibitory effects on breast cancer cells (Grossmann et al., 2009).

The results regarding physicochemical parameters, bioactive compounds and antioxidant activity are presented in Table 3.

The fruit pulp of bitter melon had a $\mathrm{pH}$ of 5.46, and the seed 6.34. Acidity is associated to $\mathrm{pH}$, and the verification of these physicochemical factors is important, as it indicates a relationship with the balance between sugars, amino acids and organic acids, and has an influence on the quality of the final product (Ferreira \& Aquila, 2000).

The vitamin $\mathrm{C}$ content found in the fruit pulp was lower than found by $\mathrm{Ng}$ \& Kuppusamy (2019), of $20 \mathrm{mg} 100$ $\mathrm{g}^{-1}$ (d.b.) using the methodology of L-ascorbic acid oxidase and analytical curve in HPLC. This difference in content may be due to the way in which the result is expressed, as we use the unit of measurement on a wet basis, and if converted to a dry basis, the concentration would be similar.

The high content of vitamin $\mathrm{C}$, in addition to indicating the importance of the fruit as a supplier of an important nutritional compound as described by Ng \& Kupussamy (2019), can also be considered a reducer of reactive oxygen species, as the antioxidant activity is directly related with the prevention of several types of cancer, as reported by Sur \& Ray (2020).

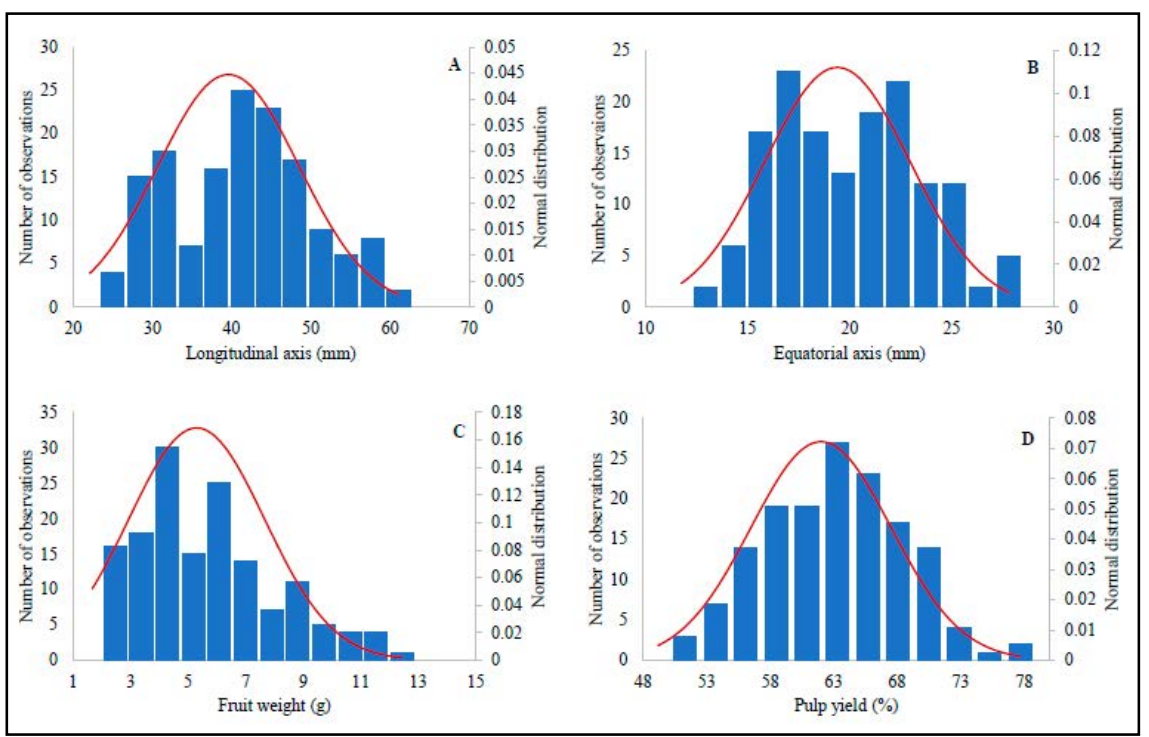

Figure 2. Number of observations and normal distribution of the longitudinal axis (A), equatorial axis (B), fruit weight (C), and pulp yield (D) of the bitter melon. Rio Verde, IFGoiano, 2020.

Table 2. Pearson's correlation coefficient (R) from biometrics data of bitter melon. Rio Verde, IFGoiano, 2020.

\begin{tabular}{lc}
\hline Comparisons & $\mathbf{R}$ \\
\hline Longitudinal axis x Equatorial axis & 0.804 \\
Longitudinal axis x Pulp yield & 0.859 \\
Longitudinal axis x Fruit weight & 0.860 \\
Equatorial axis x Pulp yield & 0.879 \\
Equatorial axis x Fruit weight & 0.880 \\
Fruit weight x Pulp yield & 0.983 \\
\hline
\end{tabular}

According to UV/Vis spectra (Figure 3), of readings from 400 to $600 \mathrm{~nm}$, it was possible to identify maximum absorptions in the pulp ether extract at 445 and $474 \mathrm{~nm}$, and in the seeds ether extract at 445, 470 and $499 \mathrm{~nm}$. Pacheco et al. (2012), extracting lycopene from arils of bitter melon seeds, observed maximum absorptions at 445, 472 and $503 \mathrm{~nm}$.

The lycopene content was lower than that found in the cited research. This difference can be explained by the geografic location of fruit harvest or by the efficiency of the extraction process, as they used column chromatography in order to produce standards with high purity, while in this work, the extraction had no such objective, dispensing the chromatography.

About the value of $\beta$-carotene found in the fruit pulp extract, it is estimated around $180 \mu \mathrm{g}$ of retinol per $100 \mathrm{~g}$, because $1 \mu \mathrm{g}$ of $\beta$-carotene being equivalent to $0.167 \mu \mathrm{g}$ of retinol (BRASIL, 2005). The bitter melon showed a higher $\beta$-carotene content than that found by Khoo et al. (2011) in mango and pineapple, showing its potential to offer this vitamin when consumed.

The antioxidant activities of pulp and seeds were different, with $75 \%$ in the seed. Yoshime et al. (2019) also obtained antioxidant activity values greater than $50 \%$ in the methods used, and attributed this high capacity to the presence of tocopherol and other bioactive compounds present in the bitter melon seed oil.

The phenolic compounds content and flavonoids were similar to those found by Chung et al. (2016), in root extracts from the same plant. Despite being from different parts of the plant, it is an important attribute to explain the high antioxidant capacity. Thus, the antioxidant potential of the seeds of this fruit can be attributed to the high concentrations of flavonoids, tannins and total phenolic compounds.

The antioxidant capacity of bitter melon fruit extracts is associated to levels of flavonoids, carotenoids and total phenolic compounds. Furthermore, the high levels of tannins and flavonoids are associated with a reduction in 
Table 3. Physicochemical caracterization, bioactive compounds and antioxidante activity of bitter melon pulp and seeds. Rio Verde, IFGoiano, 2020.

\begin{tabular}{ccccccccc}
\hline & pH & ATT & Vit C & CT & CFT & T & AAT & F \\
\hline $\mathrm{P}$ & $5.46 \pm 0.05$ & $2.85 \pm 0.36$ & $11.57 \pm 2.99$ & $21.49 \pm 0.03$ & $31.02 \pm 0.95$ & $0.54 \pm 0.15$ & $9.06 \pm 0.34$ & $223.46 \pm 5.33$ \\
$\mathrm{~S}$ & $6.34 \pm 0.05$ & $2.04 \pm 0.46$ & $10.42 \pm 1.54$ & $10.54 \pm 0.05$ & $55.75 \pm 1.90$ & $1.24 \pm 0.25$ & $75.89 \pm 3.48$ & $256.79 \pm 7.40$ \\
\hline
\end{tabular}

$\mathrm{P}=$ pulp; $\mathrm{S}=$ seed; $\mathrm{ATT}=$ total titratable acidity $(\%) ; \mathrm{Vit} \mathrm{C}=$ vitamin $\mathrm{C}\left(\mathrm{mg} 100 \mathrm{~g}^{-1}\right) ; \mathrm{CT}=$ total carotenoids $\left(\mu \mathrm{g} \mathrm{g}^{-1}\right) ; \mathrm{T}=$ tannins $(\%) ; \mathrm{CFT}=$ phenolic total compounds (mg GAE $\left.100 \mathrm{~g}^{-1}\right) ; \mathrm{AAT}=$ antioxidant activity $(\%)$; $=$ flavonoids (mg of pyrocatechin $\left.100 \mathrm{~g}^{-1}\right)$.

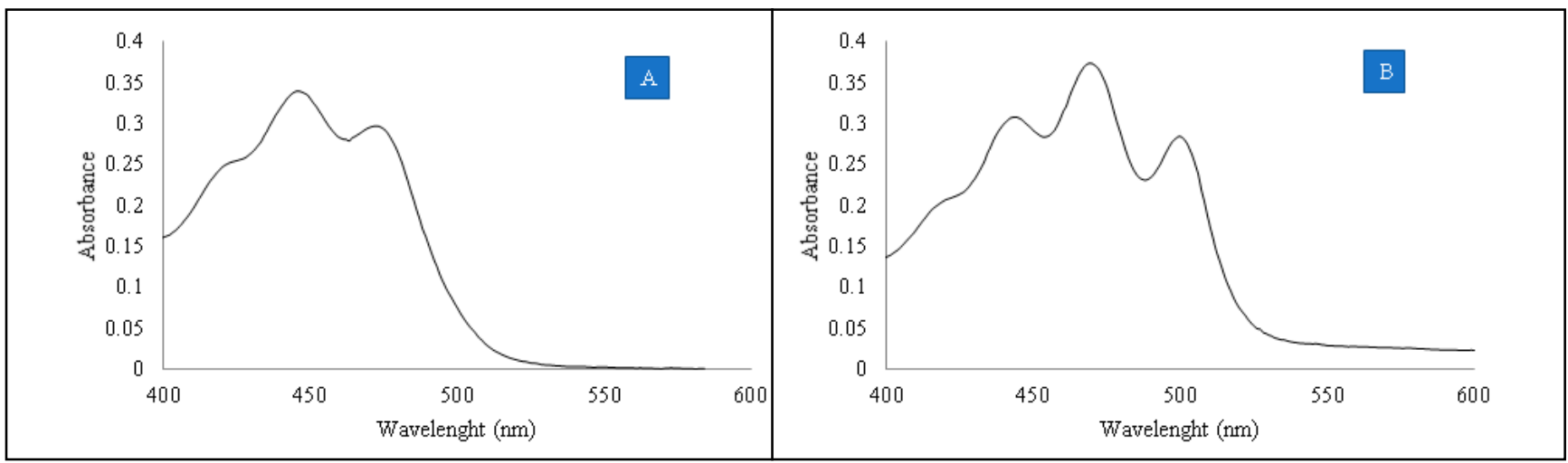

Figure 3. UV/vis absorbance spectra of pulp (A) and seeds (B) of bitter melon in petroleum ether with readings from 400 to $600 \mathrm{~nm}$. Rio Verde, IFGoiano, 2020.

inflammatory reactions, as reported by Bortolotti et al. (2019).

From the context presented, some final considerations can be made. As the plants used for collection were native, not having been developed with specific management or genetic improvement, the biometric characteristics showed high variability. However, the pulp yield and the physicochemical characteristics of the fruit showed viability for its application in industrial scale.

The high bioactive compounds content, as total phenolics, flavonoids, carotenoids and vitamin A, gave Momordica charantia high antioxidant activity, which correlated with its protein and lipid content, indicate the fruit as a promising raw material for the development of food formulations characterized as functional foods and potentially effective drugs in the treatment of diabetes and degenerative diseases such as cancer.

\section{ACKNOWLEDGMENTS}

The authors acknowledge the support from Instituto Federal Goiano, phytochemistry laboratory and CNPq.

\section{REFERENCES}

ASSIS, JP; SOUSA, RP; LINHARES, PCF; PEREIRA, MFS; MOREIRA, JC. 2015. Avaliação biométrica de caracteres do melão de São Caetano (Momordica charantia L). Revista Brasileira de Plantas Medicinais 17: 505-514.

BORTOLOTTI, M; MERCATELLI, D; POLITO, L. 2019. Momordica charantia, a nutraceutical approach for inflammatory related disease. Frontiers in Pharmacology 10: 1-9.

BRASIL. Agência Nacional de Vigilância Sanitária (Anvisa). 2005. Resolução da Diretoria Colegiada - RDC N ${ }^{\circ} 269$ de 22 de setembro de 2005. Available: http://www. anvisa.gov.br/alimentos/legis/especifica/ regutec.htm

CARVALHO, JEU; MULLER, CH. 2005. Biometria e rendimento percentual de polpa de frutas nativas da Amazônia. EMBRAPA. Amazônia Oriental-Comunicado Técnico (INFOTECA-E). Availble: http://www. infoteca.cnptia.embrapa.br/infoteca/handle/ doc/404792

CELOTO, MIB; PAPA, MFS; SACRAMENTO, LVS; CELOTO, FJ. 2011. Atividade antifúngica de extratos de Momordica charantia L. sobre Colletotrichum musae. Revista Brasileira de Plantas Medicinais 13: 337-341.

CHITARRA, MIF; CHITARRA, AB. 2005. Póscolheita de frutos e hortaliças: fisiologia e manuseio. Lavras, BR: FAEPE. 785p.

CHUNG, Ill-M; THIRUVENGADAM, M; REKHA, K; RAJAKUMAR, G. 2016.
Elicitation enhanced the production of phenolic compounds and biological activities in hairy root cultures of bitter melon (Momordica charantia L.). Brazilian Archives of Biology and Technology 59: 1-10.

DAVIES, BH. Carotenoids. In: GOODWIN, TW (ed). 1976. Chemistry and biochemistry of plant pigments. London, UK: Academic press. p.38-65.

FANG, EF; FROETSCHER, L; SCHEIBYEKNUDSEN, M; BOHR, VA; WONG, JH; NG, TB. 2019. Atividades antitumorais emergentes do melão amargo (Momordica charantia). Current Protein and Peptide Science 20: 296-301.

FERREIRA, AG; AQUILA, MEA. 2000. Alelopatia: uma área emergente da ecofisiologia. Revista Brasileira de Fisiologia Vegetal 12: 175-204.

GROSSMANN, ME; MIZUNO, NK; DAMMEN, ML; SCHUSTER, T; RAY, A; CLEARY, MP. 2009. Eleostearic acid inhibits breast cancer proliferation by means of an oxidationdependent mechanism. Cancer Prevention Research 2: 879-886.

KHOO, HE; PRASAD, KN; KONG, KW; JIANG, Y; ISMAIL, A. 2011. Carotenoids and their isomers: color pigments in fruits and vegetables. Molecules 16: 1710-1738.

KIM, SK; JUNG, JJ; JUNG, HJ; YOON, $\mathrm{N}$; KANG, SS; ROH, GS; HAHM, JR. 2020. Hypoglycemic efficacy and safety of Momordica charantia (bitter melon) in patients with type 2 diabetes mellitus. Complementary Therapies in Medicine 52: e102524.

MACEDO, IYL; GARCIA, LF; NETO, JRO; LEITE, KCS; FERREIRA, VS; GHEDINI, 
PC; GIL, ES. 2017. Electroanalytical tools for antioxidant evaluation of red fruits dry extracts. Food Chemistry 217: 326-331.

MADALA, NE; PIATER, L; DUBERYA, I; STEENKAMP, P. 2016. Distribution patterns of flavonoids from three Momordica species by ultra-high performance liquid chromatography quadrupole time of flight mass spectrometry: a metabolomic profiling approach. Brazilian Journal of Pharmacognosy 26: 507-513.

MAKKAR, HPS. 2000. Quantification of tannins in tree foliage [Laboratory Manual]. Viena: FAO.

MENSOR, LL; MENEZES, FS; LEITÃO, GG; REIS, AS; SANTOS, TC; COUBE, CS; LEITÃO, SG. 2001. Screnning of Brazilian plant extracts for antioxidant activity by the use of DPPH free radical method. Phytotherapy Research 15: 127-130.

NG, ZX; KUPPUSAMY, UR. 2019. Effects of different heat treatments on the antioxidant activity and ascorbic acid content of bitter melon, Momordica charantia. Brazilian Journal of Food Technology 22: 1-9.

PACHECO, S; GODOY, RLO; PORTE, A; ROSA, JS; SANTIAGO, MCPA. 2012. Obtenção de padrões de cis-licopeno e $\beta$-criptoxantina para cromatografia líquida de alta eficiência a partir de melão de São Caetano e Caqui. Ciências Biológicas e da Saúde 14: 81-86.
PEDRON, FA; MENEZES, JP; MENEZES, NL. 2004. Parâmetros biométricos de frutos, endocarpos e sementes de butiazeiro. Ciência Rural 34: 585- 586.

POOVITHA, S; PARANI, M. 2017. Protein extract from the fruit pulp of Momordica charantia potentiate glucose uptake by upregulating GLUT4 and AMPK. Journal of Functional Foods 37: 507-512.

SANTANA, SH; TORRES, SB; BENEDITO, CP. 2013. Biometria de frutos e sementes e germinação de melão-de-são-caetano. Revista Brasileira de Plantas Medicinais 15: 169-175.

SILVA, QJ; FIGUEIREDO, FJ; LIMA, VLAG. 2016. Características físicas e químicas de cirigueleiras cultivadas na Zona da Mata Norte de Pernambuco. Revista Ceres 63: 285-290.

SOUZA, CO; MENEZES, JDS; RAMOS NETO, DC; ASSIS, JGA; SILVA, SR; DRUZIAN, JI. 2012. Carotenoides totais e vitamina A de curcubitáceas do Banco Ativo de Germoplasma da Embrapa Semiárido. Ciência Rural 42: 926-933.

SUR, S; RAY, RB. 2020. Bitter melon (Momordica charantia), a nutraceutical approach for cancer prevention and therapy. Cancers 12: 1-22.

TAN, SP; KHA, TC; PARKS, SE; ROACH, PD. 2016. Bitter melon (Momordica charantia L.) bioactive composition and health benefits:
A review. Food Reviews International 32: 181-202.

THIRUVENGADAM, M; PRAVEEN, N; MARIA JOHN, KM; YANG, YS; KIM, SH; CHUNG, IM. 2014. Establishment of Momordica charantia hairy root cultures for the production of phenolic compounds and determination of their biological activities. Plant Cell, Tissue and Organ Culture 118: 545-557.

YOSHIME, LT; MELO, ILP; SATTLER, JAG; TORRES, RP; MANCINI-FILHO, J. 2019. Bioactive compounds and the antioxidant capacities of seed oils from pomegranate (Punica granatum L.) and bitter gourd (Momordica charantia L.). Food Science and Technology 39: 571-580.

YUWAI, KE; RAO, KS; KALUWIN, C; JONES, GP; RIVETT, DE. 1991. Composição química de frutos de Momordica charantia L. Journal of Agricultural and Food Chemistry 39: 1762-1763.

ZENEBON, O; PASCUET, NS; TIGLEA, P. 2008. Métodos físico-químicos para análise de alimentos. São Paulo: Instituto Adolfo Lutz. 1020p.

ZUFFO, AM; ANDRADE, FR; ZUFFO-JÚNIOR, JM. 2014. Caracterização biométrica de frutos e sementes de baru (Dipteryx alata Vog.) na região leste de Mato Grosso, Brasil. Revista de Ciências Agrárias 37: 463-471. 